\title{
ПРИНЦИПИ ВЕДЕННЯ ІННОВАЦІЙНОЇ ДІЯЛЬНОСТІ НА ПІДПРИЕМСТВАХ
}

\section{PRINCIPLES OF INNOVATIVE ACTIVITY AT ENTERPRISES}

\author{
Ткаченко Поліна Володимирівна \\ аспірантка, \\ Київський національний економічний університет \\ імені Вадима Гетьмана \\ ORCID: https://orcid.org/0000-0001-6097-3064 \\ Tkachenko Polina \\ Kyiv National Economic University named after Vadym Hetman
}

\begin{abstract}
Стаття присвячена особливостям ведення інноваційної діяльності на підприємствах, а саме в розрізі принципів управління інноваційною діяльністю. Автором розглянута сукупність принципів, якими можна керуватись при здійсненні інноваційної діяльності на підприємстві. Зазначається важливість застосування принципу системності та окремо розглядаються його п'ять складових, які дозволяють сформувати ефективну організацію із взаємозалежними елементами. Підкреслена важливість визначення класифікації інновацій при веденні інноваційної діяльності та виявлено можливість групувати принципи згідно із класисрікацією, що застосовується на підприємстві. Автором було згруповано принципи згідно власної класифікації, визначивши базис і надбудови, що дало змогу побудувати їх ієрархію. Представлене групування може допомогти визначити необхідних набір принципів для управління інноваційною діяльність згідно виду інновацій, які запроваджуються на підприємстві.

Ключові слова: інновації, інноваційна діяльність, управління інноваційною діяльністю, принципи інноваційної дільності.
\end{abstract}

Статья посвящена особенностям ведения инновационной деятельности на предприятиях, а именно в разрезе принципов управления инновационной деятельностью. Автором рассмотрена совокупность принципов, которыми можно руководствоваться при осуществлении инновационной деятельности на предприятии. Отмечается важность применения принципа системности и отдельно рассматриваются его пять составляющих, которые позволяют сформировать эфроективную организацию с взаимозависимыми элементами. Подчеркнута важность определения классификации инноваций при ведении инновационной деятельности и выявлены возможность группировать принципы по классисикации, применяемой на предприятии. Автором были сгруппированы принципы согласно собственной классификации, определив базис и надстройки, что позволило построить их иерархию. Представленное группирование может помочь определить необходимые набор принципов для управления инновационной деятельности согласно вида инноваций, которые вводятся на предприятии.

Ключевые слова: инновации, инновационная деятельность, управление инновационной деятельностью, принципы инновационной деятельности.

Today, innovation in enterprises is the key to maintaining market position and ensuring a stable level of competitiveness. However, the issue of effective management of innovation is relevant, which raises the question of principles and tools that can be applied in the enterprise. The main purpose of the article is to consider the principles and their classification in order to effectively achieve management goals in the implementation of innovative activities in the enterprise. In writing such articles, general scientific methods such as analysis, synthesis, induction and deduction, abstraction and analogy, were used to determine the relationship between types of innovation in entrepreneurship with the innovation management principles and stimulate the hierarchy of management principles using innovation. The article is devoted to the peculiarities of innovation in enterprises, namely in terms of innovation management principles. The author considers a set of principles that can be followed in the implementation of innovative activities in the enterprise. The importance of applying the systematicity principle is noted and its five components are considered separately, which allow to form an effective organization with interdependent elements. The importance of determining the innovations classification in the innovative activities conduct is emphasized and the possibility of grouping the principles according to the classification used in the enterprise is revealed. The author grouped the principles according to his own classification, defining the basis and superstructures, which allowed to build their hierarchy. The presented grouping can help to define the necessary set of principles for innovative activity 
management according to the type of innovations which are introduced at the enterprise. The article will be useful to expand the theoretical innovation management knowledge and those who have faced the problem of "multiple choice" in practice, for which a the principles division of innovation according to the innovations types implemented in the enterprise to effectively manage them.

Keywords: innovations, innovative activity, management of innovative activity, principles of innovative activity.

Постановка проблеми. На сьогоднішній день, ведення інноваційної діяльності на підприємствах є запорукою підтримки позицій на ринку та забезпечення стійкого рівня конкурентоспроможності. Проте актуальним є питання ефрективного управління інноваційною діяльністю, звідки повстає питання принципів та інструментів, які можуть бути застосовані на підприємстві.

Велика кількість теоретичного обґрунтування принципів управління інноваційною діяльність потягнула за собою проблему множинного вибору. Велике різноманіття підходів до управління інноваційною діяльністю може призвести до зниження ефективності прийняття управлінських рішень та/або нівелювання її результатів.

Аналіз останніх досліджень і публікацій. Питання принципів управління інноваційною діяльністю розглядались багатьма вченими і у літературі можна зустріти велику кількість їх класифрікацій [2; 5; 8]. Так Абрамова Г.П. [1] розглядав інновації як важливу частину маркетингової діяльності підприємства і розглядав принципи управління маркетингом інновацій. Ілляшенко Н.С. [3] розглядає інноваційну діяльність як передумовою інноваційного маркетингу і в рамках свого дослідження вивчає велику кількість принципів управління інноваційною діяльністю і групує їх згідно цілей застосування інструментів інноваційного маркетингу на підприємстві. Мартиненко А.В., Перерва П.Г. [6] підкреслюють важливість управління інноваційним процесом на підприємстві та пропонують ряд інструментів для здійснення ефрективного управління інноваційною діяльністю на підприємствах. Маслак О.О. [7], Полозова Т.В., Кривцун Д.Ю. [9] вивчали проблеми ефективного управління інноваційною діяльністю та її взаємозв'язок 3 інноваційними процесами. Чумак Л.Ф. [12] підкреслив важливість впливу зовнішніх фракторів на вибір методики управління інноваційною діяльністю та залежність її перебігу від різних чинників. Яшкіна О.І. [13] досліджувала сучасні тенденції, які диктують умови ринку та в певній мірі регулюють перебіг інноваційної діяльності на підприємстві, а також залежність від цих тенденцій способів, особливостей та управління імплементацією інновацій.
Виділення невирішених раніше частин загальної проблеми. Розвиток теорії економіки та менеджменту дає можливість науково обґрунтувати складні управлінські рішення, проте одночасно з тим ускладнює вибір інструментів управління інноваційною діяльністю. У економічній літературі не представлено групування принципів управління інноваційною діяльністю на підприємствах згідно особливостей самого підприємства, що, в свою чергу, створює проблему множинного вибору і ускладнює задачу прийняття управлінського рішення.

Формулювання цілей статті. Основною метою статті $€$ розгляд принципів та їх класифрікація 3 метою ефрективного досягнення управлінських цілей при здійсненні інноваційної діяльності на підприємстві.

\section{Виклад основного матеріалу дослід-} ження. У літературі виділяється велика кількість концепцій для управління промисловим підприємством через призму інноваційної стратегії. Найчастіше автори [2; 3; 5] пропонують керуватись наступними принципами при побудові інноваційної стратегії:

1. Використання принципу орієнтації підприємства на інноваційний шлях розвитку. Такий шлях розвитку передбачає роботу підприємства на шляху пошуку і використання свого інноваційного потенціалу у ссрерах розвитку виробництва, продукції та організації управління роботи підприємства.

2. Використання принципу орієнтації на споживачів. Цей принцип передбачає постійний моніторинг попиту на продукцію підприємства та рівня задоволення споживачів. 3 цього випливає потреба в проведенні регулярних маркетингових досліджень.

3. Використання принципу орієнтації на працівників. Принцип обумовлює постійне підвищення кваліфрікації працівників та підбір висококваліфікованих кадрів, а також орієнтація на задоволення їх потреб та участь у прийнятті управлінських рішень. Оскільки інновації $€$ результатом виникнення ідей, працівники можуть виступати джерелом ідей покращу вальних інновацій принаймні на рівні організації управління роботи підприємства. Тому, для інноваційно-орієнтованих підприємств важливо надавати можливість працівникам висловлювати свої ідеї. 
4. Використання принципу забезпечення максимізації прибутку за умови створення максимально комсоортних умов для працівника. У багатьох дослідженнях йдеться про те, що працівники максимально ефрективні у комфортних для себе умовах, звідси випливає, що для ефективної роботи підприємства і максимального прибутку.

5. Використання принципу наукового обґрунтування обраної системи управління. Даний принцип передбачає в процесі організації системи управління підприємства в цілому, керуватись чинним законодавством та законами економіки, в тому числі, керуватись принципами, які в кінцевому підсумку сприятимуть ефрективній роботі підприємства. Даний принцип стосується не тільки інноваційної діяльності, а щоденної звичайної діяльності підприємства.

6. Використання принципу збереження та розвитку конкурентних переваг. Полягає у виявленні слабких і сильних сторін підприємства для визначення та підвищення рівня конкурентоспроможності на ринку.

7. Використання принципу системності. Принцип передбачає розгляд підприємства як єдиної системи, яка включає в себе різні взаємопов'язані підсистеми. Проте, підприємство, яке займається інноваційною діяльністю має відкритий тип організаційної системи, оскільки адаптація під тенденції ринку передбачає великий вплив зовнішніх факто- рів. Авторами [8] виділяють окремо принципи системності, розглянуті на рисунку 1.

8. Використання принципу правової регламентації управління. Полягає у дотриманні законодавчих норм при організації процесів управління на підприємстві. Цей принцип є особливо важливим для інноваційної діяльності, оскільки законодавча база, яка регламентує ведення інноваційної діяльності та права інтелектуальної власності ще недостатньо розвинута.

9. Використання принципу єдності теорії та практики управління. Регламентує те, що всі управлінські рішення мають піддаватись логіці, методам та принципам управління, а також вирішувати практичну задачу [5]. Тобто при веденні інноваційної діяльності на підприємстві, а особливо, при імплементації якоїсь інновації у діяльність підприємства, необхідно зважати на адекватність та доцільність ії і розуміти чи не суперечить вона цілям підприємства, а також чи не виникають колізії із методами і принципами менеджменту, що використовуються на підприємстві.

10. Використання принципу співставлення варіантів управлінських рішень при їх виборі. При прийнятті управлінських рішень необхідно порівнювати їх із альтернативними рішеннями задля того, щоб рішення було чітко аргументованим за важливими для підприємства критеріями, наприклад: час, якість, рівень освоєння, срактори ризику тощо.

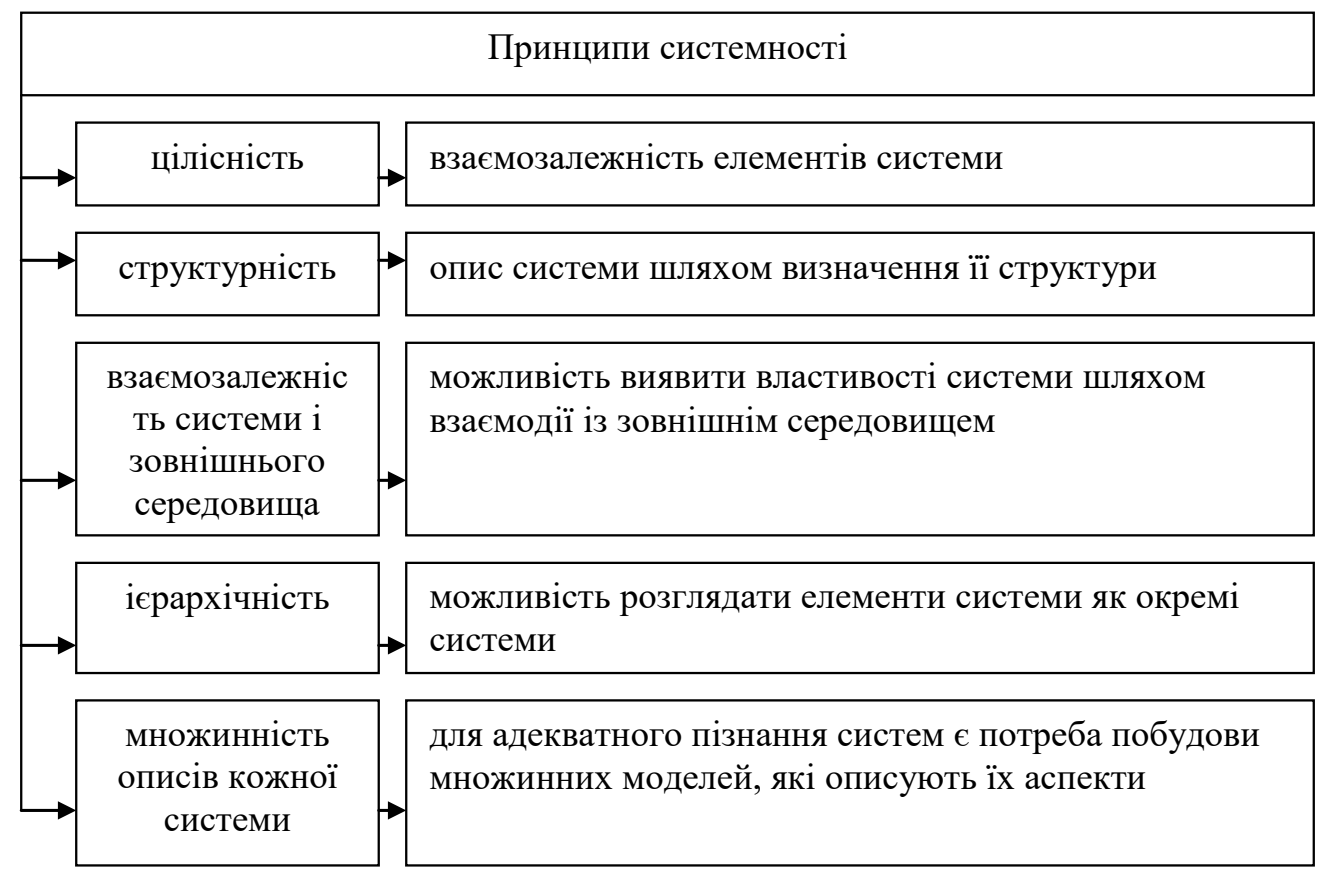

Рис. 1. Опис принципів системності

Джерело: складено автором на основі [2] 
Авторами наводяться різне групування цих принципів [3], ми пропонуємо групувати їх згідно рівнів інновацій, які були виділені нами раніше [11]. Згідно того групування, інновації поділяються на 4 рівні:

1. Базисний - інновації, що стосуються організації роботи підприємства.

2. Базис з надбудовою - інновації, що стосуються удосконалення процесів.

3. Базис з надбудовою другого рівня - інновації, що стосуються маркетингу.

4. Базис з надбудовою третього рівня інновації, що стосуються кінцевого продукту.

Зацією класифрікацією інновацій, ми можемо поділити принципи таким чином (рис. 2).

Очевидно, що кожний із принципів може застосовуватись для будь-якого виду інновацій, проте на кожному рівні $\epsilon$ більш і менш значущі для кожного виду інновацій.

Так, не випадково нами було розділено принципи правової регламентації управління і принципи наукового обґрунтування управління, які за своєю суттю дотичні, оскільки на базисному рівні фрормується організація як цілісна система і правові закони превалюють над законами економіки і менеджменту, тому вважаємо, що в першу чергу, організація має керуватись законодавчими актами, а потім, виходячи із цього науково обґрунтовувати свою подальшу управлінську організацію.

Представлену на рисунку 2 схему можна умовно розділити на 2 частини, де базис і надбудова I рівня стосуються внутрішньої роботи підприємства, а надбудови II і III рівнів орієнтуються на взаємодію із зовнішнім середовищем, тому нами було розміщено принципи у такій послідовності.

Висновки. Сучасні тренди диктують підприємствам умови діяльності, через що на перший план виходить інноваційна діяльність підприємств, яка допомагає підприємствам втримувати свої конкурентні позиції на ринку.

Для ефрективної організації діяльності взагалі, а також інноваційної, необхідно керуватись науковим підходом та обґрунтованими управлінськими рішеннями. Для цього було розглянута та виділена обмежена сукупність принципів за якими може вестись інноваційна діяльність на підприємствах. Окрім загальних принципів, були розглянуті принципи системності, який класифрікується автором як принцип базисного рівня, через що вважаємо, що йому слід приділити більшу увагу при застосуванні їх на практиці.

Представлений перелік принципів для ведення інноваційної діяльності був згрупо-

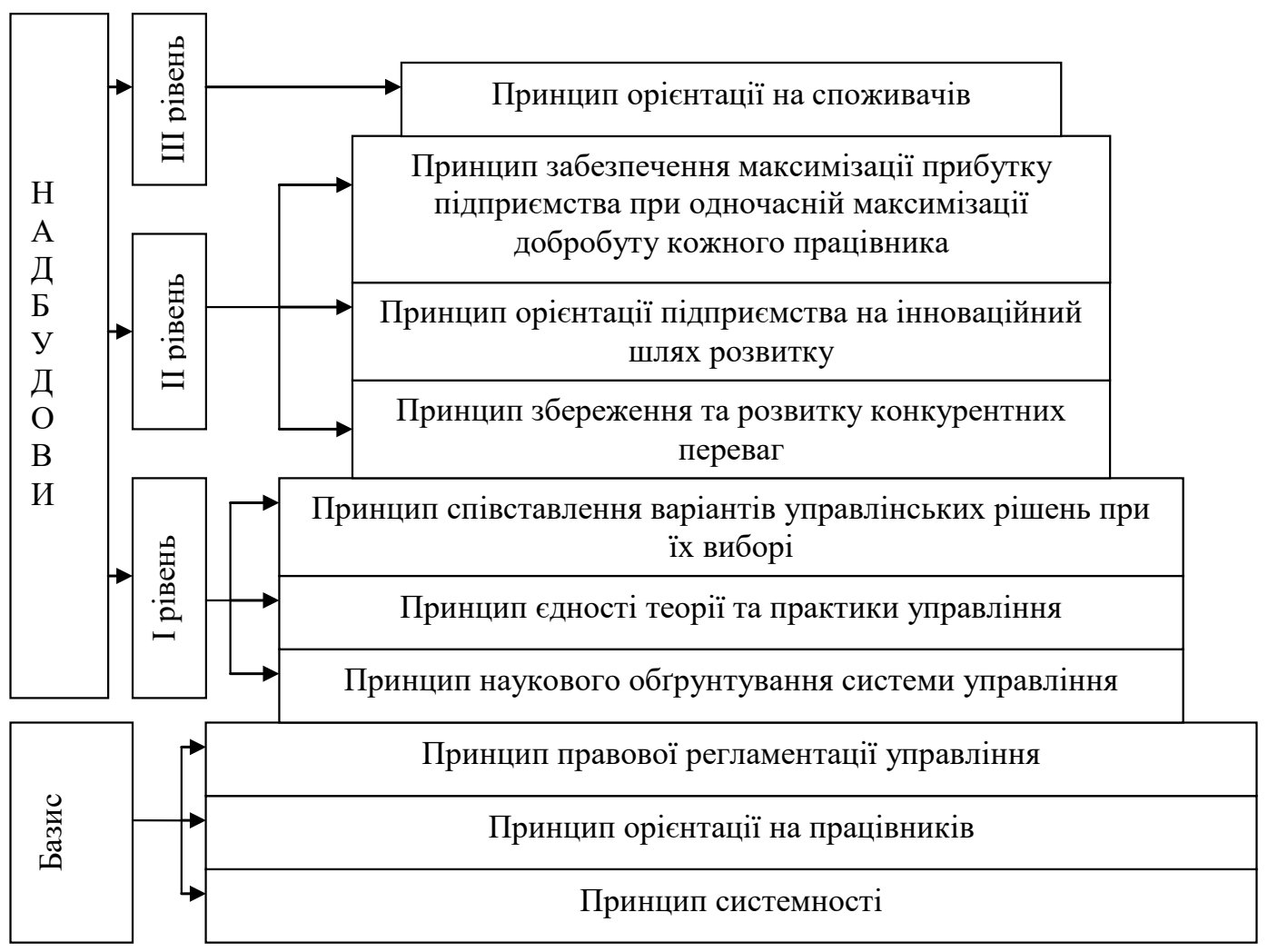

Рис. 2. Групування принципів управління за рівнями інновацій 
ваний відповідно до класифрікації рівнів інновацій, запропонованих автором. Дана класифрікація являє собою ієрархію інновацій на підприємстві, та визначає ступінь взаємодії імплементованих на підприємствах інновацій із зовнішнім середовищем підприємства.

Відповідно до цього поділу, стає можливим обмежити інструменти управління інноваційною діяльністю на підприємстві, згідно того яка інновація буде застосовуватись та яка її сорера впливу.
Подальші наукові дослідження передбачають вивчення інструментарію управління інноваційною діяльність на підприємстві в цілому, а особливо в розрізі системи управління витратами на інноваційну діяльність. Виходячи із набору обраних для підприємства принципів ведення інноваційної діяльності, можливий вибір методу управління витратами на інноваційну діяльність та його коригування згідно концепцій фрункціонування самого підприємства.

\section{СПИСОК ВИКОРИСТАНИХ ДЖЕРЕЛ:}

1. Абрамова Г.П. Маркетинг инноваций / под ред. Абрамовой Г.П., Касаева Б.С. Москва : Инфрра-М, 2003. 173 С.

2. Банківський менеджмент : Підручник / За ред. О.А. Кириченка, В.І. Міщенка. Київ : Знання, 2005. 831 с.

3. Ілляшенко Н.С. Організаційно-економічні засади інноваційного маркетингу промислових підприємств : монограсія. Суми : «Вид-во СумДУ», 2011. 192 с.

4. Керівництво (рекомендації) Осло 2018. Керівні принципи збору, звітності та використання даних про інновації : OЕСD та Євростат, 2018. 300 с.

5. Менеджмент для бакалаврів : Підручник. У двох томах. Т. 1 / За ред. О.Ф. Балацького, О.М. Теліженка. Суми : Університетська книга, 2009. 605 с.

6. Мартиненко А.В., Перерва П.Г. Інноваційний процес як основа ефективної діяльності підприємства. Теоретичні та практичні дослідження молодих науковців : праці XIII Міжнар. наук.-практ. конфр. магістрантів та аспірантів, м. Харків, 19-22 листопада 2019 р. Харків, 2019. С. 350.

7. Маслак О.О. Чинники впливу на інноваційну діяльність промислових підприємств. Науковий вісник НЛтУ України. 2012. № 22.8. С. 269-274.

8. Пит Г. Уточнение содержания контролинга как функции управления и его піддержки. Проблемы теории и прктики управления. 2001. № 3. С. 102-107.

9. Полозова Т.В., Кривцун Д.Ю. Інноваційна діяльність підприємства та економічна сутність інноваційного процесу. Науковий вісник Міжнародного гуманітарного університету. 2015. № 12. С. 108-113.

10.Про інноваційну діяльність: Закон України від 4 лип. 2002 року № 40-IV / Верховна Рада України. URL: https://zakon.rada.gov.ua/laws/show/40-15\#Text (дата звернення: 22.08.2021).

11.Ткаченко П.В. Теоретичне підґрунтя інноваційної діяльності підприємств. Підприємництво та інновації. 2021. № 19.

12. Чумак Л.Ф. Інноваційна діяльність підприємства в сучасних умовах. Бізнес Інформ. 2012. № 12. C. 209-212.

13.Яшкіна О.І. Інноваційна діяльність підприємств України: тенденції розвитку та чинники впливу. Маркетинг і менеджмент інновацій. 2013. № 4. С. 181-189.

\section{REFERENCES:}

1. Abramova H.P. (2003) Marketynh innovatsyi [Marketing innovations] / In Abramova H.P., Kasaeva B.S. (Eds.) Moskow: Ynfra-M. (in Russian)

2. Kyrychenko O.A. (2005) Bankivskyi menedzhment [Bank management] / In Kyrychenko O.A., Mishchenko V.I. (Eds.) Kyiv: Znannia. (in Ukrainian)

3. Illiashenko N.S. (2011) Orhanizatsiino-ekonomichni zasady innovatsiinoho marketynhu promyslovykh pidpryiemstv [Organizational-economic ambush of innovative marketing of industrial enterprises]. Sumy: «Vyd-vo SumDU». (in Ukrainian)

4. OECD (2018) Kerivnytstvo (rekomendatsii) Oslo 2018. Kerivni pryntsypy zboru, zvitnosti ta vykorystannia danykh pro innovatsii [Guidelines (recommendations) Oslo 2018. Guidelines for the collection, reporting and use of data on innovation]. Oslo: OECD.

5. Balatskiy O.F. (2009) Menedzhment dlia bakalavriv [Management for undergraduates] / Balatskiy O.F., Telizhenko O.M. (Eds.) Sumy: Universytetska knyha. (in Ukrainian)

6. Martynenko A.V., Pererva P.H. Innovatsiinyi protses yak osnova efektyvnoi diialnosti pidpryiemstva [Break PG Innovation process as the basis of effective enterprise activity]. Teoretychni ta praktychni doslidzhennia molodykh 
naukovtsiv (Ukraine, Kharkiv, November 19-22, 2019) (eds. Sokol E.I.), Kharkiv: Teoretychni ta praktychni doslidzhennia molodykh naukovtsiv, p. 350.

7. Maslak O.O. (2012) Chynnyky vplyvu na innovatsiinu diialnist promyslovykh pidpryiemstv [Factors influencing the innovation activity of industrial enterprises]. Naukovyi visnyk NLTU Ukrainy, no. 22.8, pp. 269-274.

8. Pyt H. (2001) Utochnenye soderzhanyia kontrolynha kak funktsyy upravlenyia y eho podderzhky [Clarification of the content of controlling as a function of management and its support]. Problemy teorii i praktiki upravlenyia, no. 3, pp. 102-107.

9. Polozova T.V., Kryvtsun D.lu. (2015) Innovatsiina diialnist pidpryiemstva ta ekonomichna sutnist innovatsiinoho protsesu [Innovative activity of the enterprise and economic essence of innovation process]. Naukovyi visnyk Mizhnarodnoho humanitarnoho universytetu, no. 12, pp. 108-113.

10. Law of Ukraine on innovation activity № 40-IV (2002, July 4). URL: https://zakon.rada.gov.ua/laws/ show/40-15\#Text

11. Tkachenko P.V. (2021) Teoretychne pidgruntia innovatsiinoi diialnosti pidpryiemstv [Theoretical basis of entrepreneurial innovative activity]. Pidpryiemnytstvo ta innovatsii, no. 19.

12. Chumak L.F. (2012) Innovatsiina diialnist pidpryiemstva $v$ suchasnykh umovakh [Innovative activity of the enterprise in modern conditions]. Biznes Inform, no. 12, pp. 209-212.

13. Iashkina O.I. (2013) Innovatsiina diialnist pidpryiemstv Ukrainy: tendentsii rozvytku ta chynnyky vplyvu [Innovative activity of Ukrainian enterprises: development trends and factors of influence]. Marketynh i menedzhment innovatsii, no. 4, pp. 181-189. 